\title{
The Readiness of Hospitals to Implement the RFID Technology
}

\author{
Seyed Mojtaba Hosseini' ${ }^{1}$, Seyed Jamaledin Tabibi ${ }^{1,}$, , Amir Ashkan Nasiripour ${ }^{1}$, Mohammad Mehdi Sepehri \\ ${ }^{1}$ Department of Health Services Management, Science and Research Branch, Islamic Azad University, Tehran, Iran \\ ${ }^{2}$ Faculty of Industrial and Systems Engineering, Tarbiat Modares University, Tehran, Iran
}

*Corresponding Author: Seyed Jamaledin Tabibi, Professor, Department of Health Services Management, Science and Research Branch, Islamic Azad University, Tehran, Iran. Email: sjtabibi@yahoo.com

\begin{abstract}
Introduction: This study is implemented with the aim of a systematic collecting and reviewing of conducted researches in connection with the implementation of the Radio-frequency identification (RFID) technology.

Methods: This study has examined the existent literatures in databases such as Google Scholar, ISI Web of Knowledge and Science Direct by using the qualitative research methods as a systematical review. The statistical society in this study consisted of archival sources that were collected and classified by the systematic review protocol and were analyzed by using the Marshall and Rasman model.

Results: There were many concerns for the use of this technology to optimize the use of RFID technology, especially in the developing country. Using the experiences of developed countries in the use of this technology and changing it according to the conditions could be a major contribution to the use of this technology.

Conclusion: Studies done in this area are limited but they will have growth, yet need culture. It is said that the use of this technology is evident in various industry and society sectors especially in the healthcare sector.
\end{abstract}

Keywords: Technology, RFID, Content Analysis, Hospitals

Article History: Received: 16 Feb. 2015; Accepted: 20 Apr. 2015; Online Published: 24 Aug. 2015

Cite this article as: Hosseini SM, Tabibi SJ, Nasiripour AA, Sepehri MM. The readiness of hospitals to implement the RFID technology. Int J Travel Med Glob Health. 2015;3(3):103-5.

\section{Introduction}

Nowadays, due to the globalized competition conditions, organizations need to increase customers' satisfaction, improve quality, expand the scope of services, reduce costs and satisfaction of human resources at the same time. In such sensitive conditions, stable institutions are the only subject to guarantee continuous improvements in the organizations productivity index.

Radio frequency identification is a technology using electromagnetic fields and attaching a label used to identify objects today. The RFID technology is a general term for the technologies that use the radio waves to identify a person, object or other information automatically [1].

It consists of following components: [1] the label4 is affixed to product or merchandise. 2-seeker including an electronic antenna and receiver (to get tags' information). 3 controller (which can be a received information processor station) [2].

Radio' signals are emitted by a transmitter through the antenna. A relationship between a tag and the transmitter is possible by the antenna. The tag transmits data based on specific requests. The transferor is responsible for receiving data. Data can then be transferred into any computer system for processing. Antenna can integrate with transferor for a single reading /writing. Range of the radio waves emitted from a device is depended on output power and radio frequency [3].

Researchers have shown that 10 to 66 percent of main deficiencies are observed after the application of the RFID technology [4]. The ability of the RFID technology can go beyond the limitations of the barcode working by the manual scan and the ability to receive a statement at the same time. It can also operate in dangerous environments, read in a longer domain and read several tags simultaneously. Moreover, reading and writing contents repeatedly and reading at high speed are the benefits of following up at a point of time [5].

Some of the other major benefits such as increased productivity, reduced costs, saved time, fewer errors, proper control of the asset / inventory, higher security and improved management of projects and processes can be mentioned [6].

The Radio Frequency Identification has three primary applications in the medical fields including tracking equipment, tracing and tracking patients and staff. Using this technology has a great advantage for a hospital and will convert hospitals into an intelligent hospital.

Architecture systems based on the $\mathrm{Wi}-\mathrm{Fi}$ connection provides the wireless connection of hospital management to patients, staff and hospital assets. Inventory management of medications, blood bank, samples taken from patients and tracking them in a laboratory are other features of this technology. Also, other applications will be in the laundry and visitors management.

Content analysis is a management approach that helps researchers provide appropriate mixture of qualitative results and line studies and antithetic in the past, to explain now situation and identify damper structural variables on the past results. The content analysis helps researchers to achieve more accurate and reliable results than ones yield in every studies' field or the qualitative evaluation of the past studies [7].

In the recent years, automatic identification in the service sector, purchasing and distribution support, construction and material flow systems became common. This issue has empowered the management of information about people, products and commodity in transition. So this study is performed in direction of the analysis done studies' content in field of the RFID technology by the systematic review to achieve a total overview about the done studies and their results by research and in order to create a better understanding about the quantity and quality of the research in this area. Thus the purpose of this study was to answer the 
question how is the status of studies in field of the RFID technology in the healthcare sector?

\section{Methods}

This research was conducted by a systematic review of previous studies on the RFID technology in the healthcare sector. Because the goal of holistic, inductive and interpretive, materials, categories and frequent categories provided in the previous investigation and with regard to the qualitative nature of this study, rather than the statistical society have been used of the archival research units instead research units. This study included all required documents without sampling at the level of researcher's access were examined. In the first phase were checked documents that were published in the last ten years, to collect information from a protocol (data collection was developed primarily based on a report with the APA format). This form was included aspects of title, authors, year of implementation, magazine, results and proposals. In this study, in order to achieve the research goals, the following process done: definition of categories based on goals of the research, classification of criteria, development of categorizes' integrity in order to answer a research question, assess the analysis' credit, determine validity of results by using all available archival documents for researcher, review and final compilation of the report.
According to the analysis of the qualitative research, collecting data, analyzing and interpreting findings were roughly done in the same time. Totally, the data were analyzed using the Rasman and Marshall Model which stages are in following: organizing information, classifying information, asking questions, offering a model and classifying the information and codifying the report.

\section{Results}

This study tried to survey using the RFID technology in hospitals by a systematic review approach. During the search, approximately 1,000 articles were identified about the RFID technology in industries and 900 irrelevant articles were excluded from the study after examination of issues related to the healthcare. Sixty articles were excluded due to lack of full text from among 100 articles. From the 40 articles available, 28 articles were excluded due to being repetitive or due to lack of complete coverage of the studied subject. Finally, 12 descriptive articles founded entry' conditions into the study. These studies were conducted between 2004 and 2011.

As the Table 1 shows, applying experiences of the developed countries in use of this technology and its' localization according to region and conditions can be a great help for the application of this technology.

Table 1. Comparative studies conducted in the field of RFID technology

\begin{tabular}{|c|c|c|c|c|c|}
\hline Subject & Authors & $\begin{array}{c}\text { Year of } \\
\text { Performance }\end{array}$ & Magazine & Results & Proposals \\
\hline $\begin{array}{l}\text { Barcodes or RFID: The } \\
\text { battle is just beginning }\end{array}$ & $\begin{array}{c}\text { Schuerenber } \\
\text { g [9] }\end{array}$ & 2006 & $\begin{array}{l}\text { Health Data } \\
\text { Management }\end{array}$ & $\begin{array}{l}\text { RFID works more efficient than barcode. Barcode and } \\
\text { RFID both of them can be useful and effective in hospitals } \\
\text { but each of these technologies have usage adequate with } \\
\text { different departments of hospitals and can be definite for } \\
\text { various usages. }\end{array}$ & $\begin{array}{l}\text { Using RFID is much easier and } \\
\text { accurate then barcode. }\end{array}$ \\
\hline $\begin{array}{l}\text { Use of RFID for patient } \\
\text { therapy }\end{array}$ & $\begin{array}{l}\text { Kangyalvsy } \\
\text { Et al. }\end{array}$ & 2007 & $\begin{array}{l}\text { Information } \\
\text { Resources } \\
\text { Management }\end{array}$ & $\begin{array}{l}\text { RFID technology waves interference with other wireless } \\
\text { waves and interference with electromagnetic waves of } \\
\text { hospital's medical devices, maintain customers } \\
\text { t information security and avoid anonymity patient' medical } \\
\text { information are significant challenges of this technology }\end{array}$ & $\begin{array}{l}\text { Trying to precisely implement this } \\
\text { technology technically and accurately } \\
\text { and rapidly transfer data }\end{array}$ \\
\hline $\begin{array}{l}\text { Tracking RFID systems } \\
\text { social dimensions }\end{array}$ & $\begin{array}{l}\text { Fisher, } \\
\text { Monahan } \\
\text { [15] }\end{array}$ & 2008 & $\begin{array}{l}\text { International } \\
\text { Journal of } \\
\text { Medical } \\
\text { Informatics }\end{array}$ & $\begin{array}{l}\text { RFID new founded technology is rapidly converting to } \\
\text { standards in hospitals }\end{array}$ & $\begin{array}{l}\text { Training and spending time to use this } \\
\text { technology for staff, also design RFID } \\
\text { in overall frameworks and usually by } \\
\text { the designer companies jointly }\end{array}$ \\
\hline $\begin{array}{l}\text { Assessment of the } \\
\text { commercial value RFID }\end{array}$ & $\begin{array}{c}\text { Tzeng, et al. } \\
{[10]}\end{array}$ & 2008 & $\begin{array}{l}\text { International } \\
\text { Journal of } \\
\text { Economical } \\
\text { Productions }\end{array}$ & $\begin{array}{l}\text { To recognize business value by RFID technology and } \\
\text { provide a framework to encourage the organization due to } \\
\text { use of this technology }\end{array}$ & $\begin{array}{l}\text { Using this technology properly and } \\
\text { creating a unique programming for each } \\
\text { patient, general care for patients at } \\
\text { home and hospitals, to protect people } \\
\text { against diseases and provide } \\
\text { rehabilitation services }\end{array}$ \\
\hline $\begin{array}{l}\text { RFID in the healthcare } \\
\text { supply chain }\end{array}$ & $\begin{array}{l}\text { Kumar, et } \\
\text { al. [13] }\end{array}$ & 2009 & $\begin{array}{l}\text { International } \\
\text { Journal of } \\
\text { Health } \\
\text { Services } \\
\text { Quality }\end{array}$ & $\begin{array}{l}\text { Pregnant women referred for childbirth: } \\
\text { Reduction of patient's information register in reception } \\
\text { time and then empty beds rapidly are recognized after the } \\
\text { register of information in RFID labels, pregnant woman is } \\
\text { hospitalized and data is transferred to section }\end{array}$ & $\begin{array}{l}\text { Despite return of costs in long periods, } \\
\text { vast benefits of this technology will } \\
\text { compensate this problem }\end{array}$ \\
\hline $\begin{array}{l}\text { Health service management } \\
\text { system design based on } \\
\text { RFID according to } \\
\text { information system theory }\end{array}$ & $\begin{array}{l}\text { Nagi, } \\
\text { et al. }[8]\end{array}$ & 2009 & $\begin{array}{l}\text { Information } \\
\text { System }\end{array}$ & Design of system based on RFID technology in hospital & $\begin{array}{l}\text { In order to design systems based on the } \\
\text { RFID technology in hospitals, it must } \\
\text { be noted to place the RFID labels and to } \\
\text { adapt existing software with system }\end{array}$ \\
\hline $\begin{array}{l}\text { RFID Technology: it's } \\
\text { results for Healthcare } \\
\text { Systems }\end{array}$ & Oscar et al. & 2010 & $\begin{array}{l}\text { Work } \\
\text { American } \\
\text { Journal }\end{array}$ & $\begin{array}{l}\text { According to focusing healthcare department on RFID } \\
\text { technology it's predicted that healthcare system costs more } \\
\text { than } \$ 21 \text { billion in this technology }\end{array}$ & $\begin{array}{l}\text { Making appropriate technical } \\
\text { infrastructure in order to use the } \\
\text { technology, as well as preparation and } \\
\text { adoption agencies and hospitals for } \\
\text { successful implementation of this } \\
\text { technology is very important }\end{array}$ \\
\hline $\begin{array}{l}\text { RFID comprehensive } \\
\text { solution to improve safety } \\
\text { of the drug in hospitalized } \\
\text { patients }\end{array}$ & $\begin{array}{c}\text { Lopez, et al. } \\
{[20]}\end{array}$ & 2011 & $\begin{array}{l}\text { International } \\
\text { Magazine of } \\
\text { Medical } \\
\text { Information }\end{array}$ & $\begin{array}{l}\text { One of the processes which can damage a patient is a } \\
\text { mistake in the prescription of drug, although advent of } \\
\text { medication errors is almost inevitable but using } \\
\text { information technology systems can reduce these mistakes } \\
\text { and increase patients' safety }\end{array}$ & $\begin{array}{l}\text { Training staff and paying attention to } \\
\text { this fact that total confidence in } \\
\text { technology can cause errors and create } \\
\text { risks for patients }\end{array}$ \\
\hline
\end{tabular}




\section{Discussion}

Most people think that the RFID is a newfound technology. The reason of this misconception is that the RFID technology has been recently developed and applied in different organizations and industries. The RFID has been commercialized since the $70 \mathrm{~s}$, but it was not much spread due to high costs in implementing in businesses a few years ago. The turning point in the history of the RFID technology was the article that Harry Stuck published in October 1948. The article made clear the importance of using the radio waves further and also understood the next progresses related in using these technologies. The most use of the RFID has been done from 2000 onwards. For example, in 2003, the RFID identified containers in the American and its allies' war against Iraq. All companies in the supply chain system developed commercial products, from pre-production to delivery into customer use of the RFID $[11,12]$.

The RFID technology has been entered to the healthcare systems and hospitals since 2004. The first RFID chip in October 2007 that had been prepared for planting approved by the American Food and Drug Organization. Nowadays many hospitals in different countries are implementing and using this technology. Results showed that the most efficient and economical parts of the healthcare supply chain will be implemented by the RFID technology [13].

Using this technology in the pharmaceutical system is also studied. Appropriate and low risk medical treatment is based on five principles: diagnosis and prescribe right medicine, right doze, right way and right time of drug prescription which the use of the RFID gives a better realization about these principles [14].

The RFID' appliance in 20 percent of patients reduced $94 \%$ waiting time at reception, and accelerated access to equipment, as well as $48 \%$ faster clearance and better care for all patients [13]. The RFID had effected to establish interaction between medical staff and patient [15].

Cost saving and producing appropriate fields in investment are the other benefits in using the RFID technology in health care systems and hospitals [16].

In addition to the advantages and creating an intelligent organization by the RFID technology, concerns also exist in regards to using this technology, such as high costs for implementation [13], costs and the needed time to train personnel [14, 13], complexity of use [15], privacy and convenient access to patient data [16], kind of hospital structures that can affect the waves' quality and transmitted information from the RFID [17]. Also, the social and ethical dimensions in using the RFID [18], lack of complete and accurate information transmission [19], lack of required technical infrastructure, violation of privacy and the length of return on investment are the other disadvantages of this technology [16].

\section{Conclusion}

In all the described cases, in order to increase benefits using the RFID technology and to reduce its concerns, proper management, culture in the community, adequate advertising to create public acceptance and increasing awareness is required.

\section{Acknowledgments}

This paper has been extracted from a Ph.D. dissertation.

\section{Authors' Contributions}

All authors were involved in every stage of this study. All authors confirmed the final draft before submission.

\section{Financial Disclosure}

The authors declared no financial disclosure.

\section{Funding/Support}

Not declared.

\section{References}

1. Ren Z, Xue X. The assessment of RFID facilitated construction material management system - a case study of water supply project. Proceedings of the International Conference on Computing in Civil and Building Engineering, 2009.

2. Moghadam N. Evaluate the effectiveness of the application of rule RFID in inventory management using BSC. [Master Thesis]. Tehran: Payam Noor Universit, 2011. Persian

3. Ko CH. RFID 3D Location Sensing Algorithms. Automation in Construction. 2010;19(5):588-95.

4. Kim D-Y, Yoon H-G, Jang B-J, Yook J-G. Effects of reader-to-reader interference on the UHF RFID interrogation range. Industrial Electronics, IEEE Transactions on. 2009;56(7):2337-46.

5. Yin SY, Tserng HP, Wang J, Tsai S. Developing a precast production management system using RFID technology. Automation in Construction. 2009; 18(5):677-91.

6. Ren Z, Anumba CJ, Tah J. RFID-facilitated construction materials management (RFID-CMM)-A case study of water-supply project. Advanced Engineering Informatics. 2011;25(2):198-207.

7. Petticrew M, Roberts H. Systematic reviews in the social sciences: A practical guide: John Wiley \& Sons; 2008.

8. Ngai EW, Poon J, Suk F, Ng C. Design of an RFID-based healthcare management system using an information system design theory. Information Systems Frontiers. 2009;11(4):405-17.

9. Schuerenberg B. Bar codes vs. RFID: a battle just beginning. Health Data Manag. 2006;14(10):32.

10. Tzeng S-F, Chen W-H, Pai F-Y. Evaluating the business value of RFID: Evidence from five case studies. Int J Production Economics. 2008;112(2):601-13.

11. Roberti M. The history of RFID technology. RFID J. 2005:1.

12. Landt J. The history of RFID. Potentials, IEEE. 2005;24(4):8-11.

13. Kumar S, Swanson E, Tran T. RFID in the healthcare supply chain: usage and application. Int J Health Care Qual Assur. 2009;22(1):6781.

14. Peris-Lopez P, Orfila A, Mitrokotsa A, Van der Lubbe JC. A comprehensive RFID solution to enhance inpatient medication safety. Int J Med Inform. 2011;80(1):13-24.

15. Fisher JA, Monahan T. Tracking the social dimensions of RFID systems in hospitals. Int J Med Inform. 2008;77(3):176-83.

16. Carr AS, Zhang M, Klopping I, Min H. RFID technology: Implications for healthcare organizations. American J Business. 2010;25(2):25-40.

17. Wicks AM, Visich JK, Li S. Radio frequency identification applications in hospital environments. Hospital topics. 2006;84(3):39.

18. van der Togt R, Bakker PJ, Jaspers MW. A framework for performance and data quality assessment of Radio Frequency IDentification (RFID) systems in health care settings. J Biomedical Info. 2011;44(2):372-83.

19. Cangialosi A, Monaly J, Yang S, editors. Applying RFID to patient care: Challenges and opportunities. Proceeding of the Information Resources Management Association (IRMA) International Conference; 2007.

20. Peris-Lopez P, Orfila A, Mitrokotsa A, Van der Lubbe JC. A comprehensive RFID solution to enhance inpatient medication safety. Int J Med Inform. 2011;80(1):13-24. 